Red. prof. dr.
Sonja Kump
Izr. prof. dr.
Sabina Jelenc
Krašovec
Filozofska fakulteta
Univerze v Ljubljani

\title{
DRUŽINA OSTAJA POMEMBNA ZA MEDGENERACIJSKO SODELOVANJE IN UČENJE
}

\section{POVZETEK}

Zaradi sprememb v družini in v družbi nasploh (socialne, ekonomske, demografske, kulturne in politične spremembe spremlja tudi zaton jedrne družine) sta danes sodelovanje med generacijami in medgeneracijsko učenje pogosto oteženi. To odpira nove razprave o spodbujanju vzajemnosti med generacijami, kar bi poleg solidarnosti zagotavljalo tudi prenašanje dediščine in znanja. V prispevku obravnavamo spremembe $v$ (zahodni) družini, ki vplivajo na medgeneracijsko učenje in socializacijo različnih generacij. Analiziramo doživljanje treh generacij, povezano z medgeneracijskim učenjem in sodelovanjem, ter vpliv medsebojne povezanosti družinskih članov na razumevanje in vsebine vzajemnega učenja. Ugotovitve raziskave potrjujejo povezavo med odnosno bližino, vpetostjo v socialno okolje in vzajemnostjo pomoči, sodelovanja in učenja $v$ družini. Na podlagi analize študije primerov ugotavljamo, da je učenje v družini povezano z življenjskimi problemi; takšno učenje je integralni proces, ki vključuje kognitivne, emocionalne in socialne komponente. Rezultati naše raziskave tudi kažejo, da kljub raznoliki pogostosti stikov in intenziteti odnosov v različnih družinah skoraj v vsaki družini v našem vzorcu poteka neke vrste učenje, ki spodbuja sodelovanje in dajanje pomoči med generacijami ali pa vsaj pripomore k vzpostavljanju medosebnih odnosov.

Ključne besede: medgeneracijsko učenje, spremembe v družini, skupnost

\section{FAMILY REMAINS AN IMPORTANT FACTOR IN INTERGENERATIONAL COOPERATION AND LEARNING - ABSTRACT}

Changes in the family and in the society in general (social, economic, demographic, cultural and political, together with the decline of the nuclear family) tend to impede intergenerational cooperation and learning. This has brought about a renewal of discussions on how to develop mutuality between generations in order to foster solidarity and ensure transmission of heritage and knowledge. In this paper we discuss the changes occurring in the (Western) family, affecting intergenerational learning and socialization of different generations. We analyze three generations' perception of mutual learning and cooperation, the effects of interconnectedness between the family members on the understanding and contents of mutual learning. Our findings confirm a connection between relational closeness, social inclusion and mutuality for provision of help, cooperation and learning in the family. The results of the analysis of our case studies show that learning in the family has to do with solving life problems; it is an integral process, including cognitive, emotional and social components. Our study also confirms that some kind of learning is occurring in practically all the families we examined - in spite of the differences in the intensity of contacts and quality of relations in individual cases. Learning was seen to strengthen cooperation and mutual provision of help between the generations, or at least to contribute to establishment of interpersonal relations.

Keywords: intergenerational learning, family changes, community

UDK: $316.362: 374.7$

\section{UVOD}

Družine so se v zadnjem stoletju zelo spremenile - tako v starostni strukturi kot $\mathrm{v}$ generacijski sestavi, v raznolikosti oblik in funkcij ter v pričakovanjih njenih članov glede odno- sov med njimi. Na te spremembe so vplivali socialni, ekonomski, demografski, kulturni in politični dejavniki, med katerimi omenimo le nekatere bolj izstopajoče: daljšanje življenjske dobe, kriza sistema socialnega in zdravstvenega varstva, emancipacija žensk, 
krepitev individualizma, sekularizacija, kriza zaposlovanja in migracije.

$\mathrm{V}$ razumevanju in pojasnjevanju vzrokov in posledic spreminjanja družine, pa tudi v samih opredelitvah njenih razvojnih stopenj, obstajajo med pripadniki različnih družbenih teorij precejšnje razlike. Nekateri avtorji trdijo, da se je $v$ procesu modernizacije družina iz razširjene oblike, ${ }^{1}$ ki je obstajala v času predindustrijskih družb in v začetnih fazah industrializacije, postopoma spremenila v majhno jedrno ${ }^{2}$ (nuklearno) družino, kar je povezano s specifičnimi ekonomskimi in kulturnimi pogoji $\mathrm{v}$ industrijski družbi (Putney in Bengtson, 2003: 150). Drugi avtorji pa, nasprotno, zagovarjajo idejo, da v preteklosti razširjena družina ni bila nič bolj pogosta kakor danes ter da je bila jedrna družina $v$ razvitih zahodnih družbah ves čas prevladujoč tip (Harris, 2007: 155). Zagovorniki ideje, da se je jedrna družina $v$ času industrializacije razvila iz razširjene družine, menijo, da so se novonastale družbene institucije v industrijskem obdobju specializirale za manj funkcij, kar je za družino pomenilo, da so mnoge njene funkcije prevzele druge družbene institucije, npr. izobraževalne ustanove, podjetja, bolnišnice, cerkev itd., kar je vplivalo na spreminjanje funkcije in vloge družine. Družina je bila vse manj ekonomska enota proizvodnje, je pa s svojo spremenjeno sestavo in načinom delovanja podpirala drugačne potrebe ekonomskega sistema (odzivnost, hitrost prilagajanja, mobilnost itd.). Tako spremenjena družina je postala bolj neodvisna, svobodna in prilagodljiva, manj vezana na druge sorodstvene odnose, ki jih je vzpostavljala po potrebi in raznoliko. Mnogi avtorji (Popenoe, 1993; Laszloffy, 2002; Vollenwyder in drugi, 2002; Beck, 2009; Bengtson, 2001; Martin-Matthews, 2006) pa opozarjajo, da se je v 60. letih prejšnjega stoletja začel zaton jedrne družine, ki naj bi se danes kazal v tem, da družina ne opravlja več dobro dveh svojih temeljnih funkcij: vzgoje otrok in vzajemne opore v družini. To je razlog, da se danes večja pozornost namenja vprašanjem, kako spodbujati sodelovanje, solidarnost in vzajemnost med generacijami v družini in v družbi nasploh.

Družbeni prehodi od ene generacije k drugi že od nekdaj omogočajo prenašanje dediščine na mlajše. $V$ tradicionalnih družbah je bilo - tudi v daljšem časovnem obdobju - malo sprememb v prenašanju kulturne in zgodovinske dediščine s starejših na mlajše generacije, zato je vzajemno učenje potekalo po bolj ali manj ustaljenih vzorcih. V sodobnih družbah in družinah pa so se medgeneracijska razmerja bistveno spremenila, vsaka generacija na svoj način doživlja življenje in življenjske izzive. Srednja generacija je običajno odgovorna za mediacijo vplivov družbenih sprememb na mlajše (in starejše), vendar pa sta medgeneracijsko sodelovanje in vzajemno učenje pogosto oteženi (Alwin in McCammon, 2003: 28).

Prispevek začenjamo s predstavitvijo novejših raziskav o spremembah, ki se dogajajo v družini, značilni za zahodno kulturo. Temu sledi poglavje $\mathrm{z}$ razpravami o medgeneracijskem učenju, ki ga povezujemo s socializacijo, komunikacijo in odnosi v družini. V empiričnem delu analiziramo poglede treh generacij na vzajemno učenje in sodelovanje; zanima nas, kakšen vpliv imajo povezanost družinskih članov in odnosi med njimi na razumevanje in vsebino vzajemnega učenja med tremi generacijami v družini. Ugotavljamo tudi povezavo vpetosti družinskih članov v lokalno skupnost in intenziteto medgeneracijskega sodelovanja, medsebojne pomoči in učenja $\mathrm{v}$ družini.

\section{SPREMEMBE V DRUŽINI}

V preteklosti je bila funkcija (jedrne) družine zlasti vzgoja in socializacija otrok ter skrb 
za materialno in čustveno stabilnost njenih (odraslih) članov, ${ }^{3}$ kasneje pa se je temeljna funkcija družine iz strukturne enote družbene organizacije spremenila tako, da daje odnosno podporo posameznikovim potrebam (Bengtson, 2001: 3). Intenzivno in Funkcije družine prehajajo od socialno-institucionalnih $k$ emocionalno-podpornim.

poglobljeno je že $\mathrm{v}$ zgodnjih letih 20. stoletja spremembe v družini proučeval Burgess ${ }^{4}$ in ugotovil, da je družina glede funkcij postala vse bolj specializirana; produkcijsko in instrumentalno funkcijo družine je nadomestila emocionalna in subjektivna funkcija, ki označuje moderno jedrno družino (Burgess, 1960 v Putney in Bengtson, 2003). Burgess je značilnosti take družine opredelil s pojmom »tovarišijska družina« (»companionshipfamily«), pri čemer ni mislil le na družino kot strukturo ali gospodinjstvo, temveč tudi kot proces, interakcijski sistem, na katerega vpliva vsak od članov družine. Funkcije družine se torej prehajajo od socialno-institucionalnih k emocionalno-podpornim, ima pa družina še vedno tudi socializacijsko funkcijo, in sicer gre za večsmerno medgeneracijsko socializacijo. Tako vedenja enega od članov družine ni mogoče razumeti nikakor drugače kot $\mathrm{v}$ odnosu do drugih družinskih članov, do stalnih vzorcev interakcije in razvoja ter spreminjanja osebnosti skozi te interakcije.

Spremembe v družini so posledica vpliva več dejavnikov, med drugim demografskih sprememb; ena od posledic velikega podaljšanja longevitete je naraščajoča razširjenost tri-, štiri- in celo petgeneracijskih družin, s tem pa podaljševanje obdobja, ko posameznik opravlja določeno družinsko vlogo, npr. kot stari starš (Putney in Bengtson, 2003: 149). Družine imajo danes pogosto več starih članov kot članov mlajših generacij. ${ }^{5}$ Družine tvorijo različni sorodstveni odnosi, ki zaradi daljšega življenja lahko trajajo več desetletij (Bengtson, 2001: 4). Danes imamo torej pred seboj bistveno več let skupnega življenja več generacij kot kadarkoli prej v človeški zgodovini ${ }^{6}$ (Attias-Donfut in Segalen, 2002). Na podlagi tega lahko sklepamo, da bodo večgeneracijske vezi (vezi med več kot dvema generacijama) v prihodnosti vse bolj pomembne tako za posameznike kot za družino in družbo; večgeneracijske vezi bodo občasno tudi nadomestile funkcije jedrne družine. Burgess je že v 60. letih razmišljal, da se $\mathrm{z}$ uveljavljanjem »tovarišijske jedrne družine« vloga starih staršev in razširjene družine sicer nujno zmanjšuje, kljub temu pa je menil, da bo trigeneracijska družina kot omrežje odnosov ohranila svojo pomembno vlogo (pri čemer pa ne bodo več ključne le biološke sorodstvene vezi, temveč tudi nebiološka sorodstvena razmerja) (Burgess, 1960, v Putney in Bengtson, 2003: 150). Burgessove raziskave jedrne družine $^{7}$ v ZDA, s katerimi je pojasnjeval, da lahko naraščajočo kompleksnost družinskega življenja razumemo le tako, da proučujemo makrosocialni kontekst družine skozi čas (družbeno organizacijo v kontekstu socialne evolucije), hkrati pa tudi njeno mikrosocialno dinamiko, so postale pomembno izhodišče za nadaljnje raziskovanje sociologov na področju sprememb v družini in pomena medgeneracijskih vezi pri teh spremembah.

Spremembe v družini se kažejo tudi kot heterogenost družinskih oblik - poleg bioloških vezi postajajo pomembna tudi druga sorodstvena razmerja (npr. odnosi v binuklearnih družinah, ko se z vnovično poroko/partnerstvom družina razširi s sorodniki novega partnerja/partnerke - z njegovimi/njenimi otroki iz prejšnjega razmerja, starši novega partnerja/ partnerke, drugimi sorodniki). Družine se reorganizirajo, vzpostavljajo se novi tipi družin. ${ }^{8}$ Narašča število ločitev in vnovičnih porok, $s$ čimer narašča delež na novo vzpostavljenih družin, po drugi strani pa tudi enostarševskih 
družin ter zunajzakonskih skupnosti. K intenzivnim spremembam $\mathrm{v}$ družini prispeva tudi emancipacija žensk, saj se povečuje možnost za njihov neodvisni zaslužek ter pridobitev podpore sorodnikov (stari starši, zlasti stare matere) ali države pri vzdrževanju otrok, kar jim zagotavlja možnost ločenega (samostojnega) življenja ${ }^{9}$ (Goody, 2003: 230). Kot posledica intenzivnejših migracij se povečuje tudi kulturna raznolikost družin.

Nekateri teoretiki, zlasti s področja strukturno-funkcionalne teorije, v nasprotju z ugotovitvami, ki poudarjajo predvsem negativne posledice sprememb v družini, postavljajo v ospredje pozitiven pomen majhne jedrne družine, ki pomeni ločitev ene generacije od druge (odraslih otrok od staršev). Avtorji ugotavljajo, da so v taki družini mlajši lahko bolj zaposlitveno gibljivi in pospešijo svoj ekonomski razvoj. Majhna jedrna družina je denimo po mnenju Parsonsa pomembna za ekonomsko področje in moderno življenje nasploh, saj lahko starši svojim (maloštevilnim) otrokom posvetijo dovolj časa in ljubezni ter poskrbijo, da se bodo v življenju čim bolje znašli (Parsons, v Goody, 2003: 214). Moderna ekonomija naj bi po mnenju teh avtorjev podpirala ločitev jedrne družine od starejših sorodnikov (Silverstein in Bengtson, 1997: 430), kar naj bi zahtevalo funkcionalno prilagajanje tako starejših kot mlajših. Vendar pa so empirične raziskave $v$ 60. letih prejšnjega stoletja (zlasti v ZDA) pokazale, da je bilo tako sklepanje nekoliko prehitro; izkazalo se je, da odrasli otroci v večini primerov, tudi če je šlo za velike geografske razdalje, niso bili izolirani od svojih staršev, temveč da so zelo pogosto sodelovali in si vzajemno pomagali (Rosenmayer in Kockeis, 1963, v Silverstein in Bengtson, 1997: 431). Zato so sociologi družine ugotavljali, da razširjena družina ohranja medgeneracijsko kohezivnost, če ne drugače, s pomočjo komunikacijske in transportne tehnologije.
Čeprav podatki kažejo, da so javni transferji namenjeni predvsem starejšim ljudem (socialno varstvo), pa gre več medgeneracijske pomoči v obratni smeri, od starejših k njihovim otrokom. To potrjujejo tudi podatki raziskave SHARE o vzorcu pomoči starejših mlajšim, kar velja tako za finančno pomoč kot socialno oporo. Starejši v splošnem finančno bistveno bolj podpirajo svoje otroke kot otroci njih, vendar pa se s starostjo količina finančne pomoči nekoliko zmanjšuje (Albertini in drugi, 2007: 322). Potrjuje se tudi, da velik delež starejših svojim otrokom pomaga pri skrbi za vnuke: 37 odstotkov starejših (ki imajo vsaj enega otroka, ki živi zunaj gospodinjstva) pomaga svojim potomcem, tistih starejših, ki imajo vsaj enega vnuka in svojim otrokom pomagajo pri skrbi zanj, pa je 46 odstotkov. Po drugi strani pa je starejših, ki od svojih otrok prejemajo določeno socialno oporo, sorazmerno malo, vendar delež narašča s starostjo (sedem odstotkov starih od 50 do 59 in 28 odstotkov starih nad 70 let). Čeprav najstarejši respondenti (nad 70 let) - glede na mlajši kategoriji, to so stari od 50 do 59 in od 60 do 69 let - nudijo svojim otrokom količinsko nekoliko manj ur socialne opore (pomoči), pa pri finančni pomoči skoraj ni razlike (Albertini in drugi, 2007: 323). Predstavljene rezultate potrjuje tudi longitudinalna raziskava LSOG (Longitudinal Study of Generations), opravljena v letih 1975, 1996 in 1991 v ZDA, v katero je bilo vključenih 2.033 članov trigeneracijskih družin (Bengtson, 2001: 8). Ugotovili so v povprečju visoke (nadpovprečne) ravni solidarnosti med starimi starši in starši, starši in otroki, starimi starši in vnuki, rezultati pa so bili stabilni v vseh 26 letih merjenja. Potrdili so ugotovitev o »medgeneracijskem vložku«, da starejše generacije bistveno več vlagajo v odnose kot mlajše, kar vpliva tudi na njihovo percepcijo in vrednotenje medgeneracijskih odnosov (Bengtson, 2001: 8-9; Gauthier, 2002). Raziskave tudi kažejo, da 
obstajajo določeni vzorci medgeneracijske solidarnosti glede na državo, v kateri družina živi, na kar vpliva tudi režim države blaginje (Albertini in drugi, 2007: 332). Vse te ugotovitve so izziv za tezo, da bodo propad nuklearne družine in »alternativne« družinske zveze negativno vplivali na sodobno mladino. Raziskovalci ugotavljajo, da večgeneracijske družine še naprej opravljajo svojo funkcijo $\mathrm{v}$ skladu z novimi razmerami in družbenimi spremembami, pri čemer pa je pomembno latentno sorodstveno omrežje.

Za raziskovanje družine je značilna precejšnja razdrobljenost; stroke proučujejo posamezne vidike družine, ne da bi pri tem upoštevale prepletanje in spreminjanje družinskih funkcij, ki se pojavljajo zaradi vpliva različnih dejavnikov. Področja človekovega življenja, kot so delo, izobraževanje, prosti čas in politika, ki so sicer tesno povezana in je med njimi močno sovplivanje, se pri proučevanju družin pogosto pojmujejo kot med seboj ločena področja z malo vzajemne komunikacije. Longitudinalne raziskave, kjer z biografsko metodo proučujejo življenjske poti posameznikov v več generacijah ene družine (Bawin-Legros, 2002: 176), prinašajo podatke o dinamiki družinskega življenja ter razvoja posameznika in družine skozi različne socialne in zgodovinske kontekste. Takšne raziskave izhajajo iz perspektive življenjskega poteka in poskušajo pojasnjevati kompleksnost večgeneracijskosti družinskega življenja (Putney in Bengtson, 2003: 150).

\section{SODELOVANJE IN UČENJE V DRUŽINI}

Družina (v pestrosti svojih pojavnih oblik) je bila in ostaja ključni dejavnik socializacije skozi življenjski cikel. Medgeneracijsko družinsko socializacijo lahko opredelimo kot vseživljenjsko vzajemno vplivanje med gene- racijami znotraj družine, ki se dogaja v spreminjajočih se socialnih in zgodovinskih pogojih (Kemp, 2007: 859). Socializacija vključuje namerno kot tudi nenamerno prenašanje stališč in vedenja med generacijami (Clausen, 1968, v Uhlenberg in Mueller, 2003: 126), pri čemer ne gre za enosmeren proces, temveč za odnose med vsemi člani družine: med otroki in odraslimi ter med odraslimi člani družine (odnosi s partnerjem ali z odraslimi otroki, med odraslimi sorojenci, med odraslimi pripadniki različnih generacij itd.). Vsi ti odnosi vplivajo na trenutno in kasnejše življenje vseh članov družine. Ker pa je družinska dinamika pogosto podobna »vedenju za odrom « in je torej skrita, jo je zelo težko vrednotiti.

Pri proučevanju socializacije $\mathrm{v}$ družinski skupnosti lahko izhajamo iz konceptualizacije interpretativne paradigme simboličnega interakcionizma (katere predstavniki so npr. Mead, 1997; Berger in Luckmann, 1988; idr.), ki je eden temeljnih teoretičnih konceptov pri raziskovanju socializacijskih procesov v družinski interakciji. V družini namreč potekajo stalni interakcijski procesi, v katerih se reinterpretirajo socialni pomeni dejanj, situacij in pričakovanj različnih članov družine. Po teoriji simbolnih interakcionistov se posameznik ne formira sam, temveč v socialni interakciji oz. komunikaciji v družbenem odnosu, v soočanju z zanj pomembnimi drugimi. Socializacija v družini torej ni pojmovana kot »enkratno ponotranjanje družbenih in kulturnih norm v posameznikovi subjektivni strukturi, temveč je interpretativno delovanje, ki zajema vso življenjsko zgodovino posameznika« (Ule, 2000: 156). Vedenje članov družine ni izvajanje predpisanih vlog, temveč smiselna in premišljena aktivnost posameznika, ki se v posamezni družini vsakič znova opredeljuje glede na vzajemna dejanja vseh članov družine in glede na interpretacije pomenov stvari in socialnih situacij, ki se v družinski socialni 
interakciji z vzpostavljanjem odnosov in komunikacijo preverjajo, potrjujejo in zavračajo. Posameznik sicer lahko izhaja iz določenega družbenega položaja ali vloge, vendar se ta vloga spreminja pod vplivom pričakovanj posameznika in pomembnih drugih; to, kako posameznik in drugi razumejo določeno vlogo, spreminja njen pomen in opredeljuje posameznikovo uresničevanje te vloge, njegovo delovanje.

Za pojasnjevanje odnosov med člani družine bi lahko uporabili tudi »teorijo socialne izmenjave«, ki govori o odnosih med vključenimi stranmi, vzajemni soodvisnosti; pri tem sociologi proučujejo odnose in socialne strukture, ki vplivajo na vrednote, povezane $\mathrm{z}$ določenim vedenjem, in pričakovanje recipročnosti v nekem odnosu (Silverstein in drugi, 2002: S4). Dajanje drugim in vzpostavljanje pogojev za kasnejše povračilo je socialno lepilo, ki zagotavlja stabilnost v majhnih skupinah, torej tudi solidarnost $\mathrm{v}$ družini. Vzajemna odvisnost krepi kohezivnost v družinskih odnosih. Izmenjavo z drugo osebo (npr. z družinskim članom) omogočata pritrditev in emocionalna opora; izmenjava je lahko zamaknjena $\mathrm{v}$ kasnejše obdobje in ni nujno ekvivalentna vložku. Hill (1979, v Čačinovič Vogrinčič, 1992: 76) poudarja, da so pri tem pomembne različne družinske variable, tako zunanje (kompleksnost zunanjega okolja, družbene norme in vrednote, ekonomski položaj družine, sorodstvene in prijateljske mreže itd.) kot notranje organizacijske variable (družinska pravila, struktura moči, diferenciacija vlog, struktura čustev, struktura komunikacij, pretok informacij, sodelovanje med podsistemi v družini ipd.). Prav raziskovanje komunikacije in sodelovanja $\mathrm{v}$ družini, kar je tudi podlaga za vzajemno učenje, je zelo pomembno; izsledki redkih opravljenih raziskav kažejo, da je komunikacija bolj intenzivna v obstojnejših zvezah ter v tesneje povezanih družinah (prav tam: 78); v nepovezanih družinah je komunikacija šibka in neučinkovita, $v$ pretirano povezanih družinah pa tako intenzivna, da lahko onemogoča spremembe.

Reiss (v Fitzpatrick in Ritchie, 2004: 577) ugotavlja, da se družinska struktura sama po sebi ohranja v vsakodnevnih odnosih, ritualih med družinskimi člani in zlasti z različni-

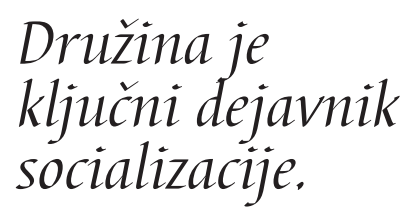
mi reprezentacijami teh interakcij, kjer se družina lahko pojavlja tudi kot možnost/enota za reševanje problemov, kriz. Informacije, ki prihajajo $\mathrm{v}$ družino, morajo biti predelane in preoblikovane $\mathrm{v}$ ustrezne rešitve in delovanje. Socialno učenje, ki poteka v družini, je torej tesno povezano s siceršnjimi interakcijami, komunikacijo in kakovostjo odnosov v družini. Ustvarjanje družinskih interakcij in vzajemnega učenja je stvar vseh članov družine, vendar pa se hkrati postavlja vprašanje, ali se pri tem morda ne dogajajo pritiski na nekatere člane družine s strani drugih. Koliko gre ob tem za težnjo po konformnosti s sprejetimi skupinskimi vrednotami? Kolikšna je možnost, da vse generacije druga na drugo vplivajo z enako intenzivnostjo in imajo enake možnosti, da so njihova stališča upoštevana in njihovi vplivi zaznani? Koliko se odnosno različno povezane družine razlikujejo glede na stopnjo medsebojne komunikacije, vzajemno socializacijo in raven vzajemnega učenja?

Učenje je vedno integralni proces, ki vključuje interakcijo in ponotranjanje naučenega, hkrati pa obsega kognitivno, emocionalno in družbeno oz. socialno komponento, ki se med seboj tesno prepletajo (Illeris, 2004: 19). Mnoge teorije učenja sicer zunanji proces interakcije in notranji psihološki proces obravnavajo ločeno, kar pa za razumevanje učenja $\mathrm{v}$ družini ni ustrezno, saj zanemarimo celostnost procesa učenja. Tudi 
pri učenju v družini gre namreč po eni strani za pridobivanje spretnosti, znanja (kognitivni proces), ključna pa sta tudi emocionalni vidik (medosebna energija, ki se prenaša s čustvi in stališči) in socialni proces, ki se ob tem odvija (interakcija med posameznikom in okoljem). Pri učenju v družini gre za intenzivno neposredno socialno interakcijo, na katero hkrati vpliva tudi družbeno okolje/socialni kontekst, kjer to učenje poteka. Carl Rogers (in tudi nekateri drugi humanistični psihologi) tako učenje poimenujejo osebno pomembno ali signifikantno učenje (»significant learning«), saj gre za učenje, ki vključuje posameznikovo celotno osebnost, torej spoznavne, čustvene in telesne funkcije, in je povezano z življenjskimi problemi (Rogers, 1994). Jarvis (1992: 73) učenje opredeljuje kot posledico razhajanja med posameznikovo biografijo in socialno ustvarjenimi izkušnjami, pri čemer se - ob samospraševanju in učenju skozi izkušnjo, tudi izkušnjo v družini - oblikuje posameznikova identiteta. Tudi v družini namreč velja, da sta glavna cilja učenja povezana $\mathrm{z}$ »biti« in »postajati«. Po Jarvisovih opredelitvah bi učenje v družini najlažje uvrstili med razmi-

\section{$\checkmark$ družini se odvi- ja socialno učenje.} šljujoče (reflektivno) učenje in ga opredelili kot izkušenjsko učenje, tudi učenje socialnih veščin (Jarvis, 1992: 76-78).

V družini se torej odvija socialno učenje, ki se dogaja zaradi interakcij z drugimi člani družine in ima lahko tudi značilnosti učenja po modelu. Wildemeersch opredeljuje socialno učenje kot »kombinirano učenje in dejavnosti reševanja problemov, ki potekajo v sodelovalnih sistemih, kot npr. v skupinah, socialnih omrežjih, gibanjih, delujejo v resničnem sistemu in tako dvigujejo raven družbene odgovornosti « (Wildemeersch, 1999, v Illeris, 2004: 135). Tudi Lave (2009) opisuje proces učenja, ki vključuje dejavnost, refleksijo, komunikacijo in pogajanja med vključenimi člani. Táko učenje se dogaja vsakodnevno, zahteva polno odgovor- nost posameznika za znanje in spretnosti, ki jih pridobiva, saj kurikula ni. Učenje je osebno, pravi učitelji so tu sorodniki; učenje poteka $\mathrm{z}$ opazovanjem in posnemanjem, pomembna je demonstracija. Posebno vlogo imajo tradicija, vztrajnost in kontinuiteta. To učenje Lave (2009: 201) uvršča med teorije situacijskega (priložnostnega) učenja $\mathrm{v}$ vsakdanjih dejavnostih (»theories of situated every day practice «), opredeljuje pa ga neformalnost, tudi priložnostnost, ko se človek vsakodnevno dotika različnih področij $\mathrm{v}$ svojem bivanju in pri odnosih v družini. Posameznik pogosto nima posebnega namena, da bi se kaj naučil, uči se delovanja in poskuša razumeti procese, ki ga obdajajo. Prihaja do mnoštva načinov izbire in poskusov, kako čim bolj kakovostno preživeti vsakdanjik. Gre za znanje, ki vključuje razumevanje, vpogled, čustva, vrednote in mnenja. Tudi Wenger poudarja, da je učenje v svojem temelju socialni fenomen; njegova socialna teorija učenja (»social theory of learning «) kot pomembne elemente učenja omenja individualno in skupinsko doživljanje smisla življenja, dejstvo, da imajo učeči se skupne zgodovinske in socialne vire, omrežja in perspektive, zaradi česar vztrajajo v skupnih dejavnostih; to učenje opredeljujejo odnosi, ki delujejo v skupini, $\mathrm{z}$ učenjem se spreminjamo in postajamo drugačni v kontekstu skupnosti, kjer učenje poteka (Wenger, 2009: 211). Družina je skupnost, kjer se z učenjem ustvarjajo skupne zgodbe, oblikujejo se dogovori, vzpostavljajo rituali, gradi zgodovina; to je lahko prostor ljubezni, sovraštva, strinjanja in nestrinjanja.

\section{METODOLOGIJA IN OPIS VZORCA}

Za proučevanje družinskega življenja $\mathrm{v}$ njegovih raznolikih kontekstih so zlasti primerne kvalitativne raziskovalne metode; običajno gre $\mathrm{v}$ teh pristopih za majhne 
vzorce in pogosto se uporabljajo za študije primera posameznih družin (Bengtson in Allen, 2004: 490). Za namene tega prispevka smo podatke zbrali v okviru kvalitativnega dela raziskave Medgeneracijska solidarnost v Sloveniji, ${ }^{10}$ kjer smo bili osredotočeni na proučevanje sodelovanja, prenašanja znanja in vrednot ter vzajemne pomoči in učenja $\mathrm{V}$ družini. V tem delu raziskave so sodelovali študenti in študentke 4. letnika študija pedagogike, smer andragogika, na Filozofski fakulteti v Ljubljani, ki smo jih predhodno usposobili za izvajanje poglobljenih polstrukturiranih intervjujev. Raziskovanje se je izvajalo spomladi 2010. Vsak študent oz. študentka ${ }^{11}$ je po vnaprej določenih navodilih opisal svojo družino in izbral primerno linijo opazovanja (študent - eden od staršev - eden od starih staršev po izbrani liniji staršev). $\mathrm{Na}$ vprašanja ${ }^{12}$ so odgovarjali odrasli otroci (študenti), njihovi starši in stari starši, na tak način smo v posamezni družini zbrali podatke in mnenja treh generacij. ${ }^{13}$

V vzorec je bilo vključenih 23 družin, skupaj je na vprašanja $\mathrm{v}$ intervjujih odgovarjalo 69 oseb. V celotnem vzorcu je bilo devet moških in 60 žensk (1. generacija: 20 žensk, trije moški; 2. generacija: 19 žensk in štirje moški; 3. generacija: 21 žensk, dva moška). Iz pridobljenih demografskih podatkov je razvidno, da $\mathrm{v}$ našem vzorcu prevladujejo ženske. Med študenti pedagogike in andragogike je namreč veliko več žensk kot moških in te so v našem primeru za linijo opazovanja najpogostejše izbrale svoje mame in babice. Povprečna starost intervjuvancev 1 . generacije je bila 24 let (v razponu od 22 do 35 let), 2. generacije 49 let (najmanj 42 in največ 60 let) in 3. generacije 75 let (v razponu od 65 do 90 let). Glede na stopnjo dosežene izobrazbe ima največji delež staršev (2. generacija) končano srednjo šolo (40 odstotkov), sledijo višja ali visoka šola (30 odstotkov), dvo- do triletna poklicna šola (21 odstotkov) in osnovna šola ali manj (devet odstotkov). Stari starši (3. generacija) imajo bistveno nižjo stopnjo izobrazbe kot njihovi otroci (2. generacija); 69 odstotkov ima dokončano ali nedokončano osnovno šolo, 13 odstotkovjih je končalo srednjo šolo in le nekaj odstotkov (pet) višjo ali visoko šolo. Iz generacije staršev je delovno aktivnih 20, trije so upokojeni, pri generaciji starih staršev so vsi upokojeni.

Zbrane podatke smo analizirali s pomočjo utemeljene teorije (Strauss in Corbin, 1990), ki omogoča identifikacijo ključnih pojmov in nakaže razmerja med njimi. Ta induktivni metodološki pristop $\mathrm{v}$ našem primeru zagotavlja poglobljeno razumevanje odkritih pojmovanj in stališč intervjuvancev ter razlago pomenskih razmerij med njimi. Analizirali smo izjave vseh intervjuvancev, v katerih so opisovali svoje razumevanje in doživljanje pomena medgeneracijskega učenja, sodelovanja in vzajemne pomoči v družini. Pri tem smo ugotavljali, kakšna je povezava med njihovim pojmovanjem in vrednotenjem učenja $\mathrm{z}$ doživljanjem odnosov v družini ter z vpetostjo in delovanjem družinskih članov $\mathrm{v}$ lokalni skupnosti. Predstavnike oz. predstavnice 2. in 3. generacije smo posebej vprašali, ali svoje znanje in izkušnje prenašajo na mlajše člane družine in kako, vprašali pa smo jih tudi, ali se radi učijo in ali bi se vključili v kakšno lokalno učno skupino.

V nadaljevanju predstavljamo študije primerov treh družin, ki smo jih izbrali glede na intenziteto medsebojne povezanosti in komunikacije treh generacij $\mathrm{v}$ družini ter vpetosti družinskih članov v skupnost (odprtost/ zaprtost). Citati, ki jih navajamo, so označeni s kodo raziskave (MSS), kodo družine, sledijo izmišljeno ime in starost intervjuvane osebe ter oznaka generacije, v katero je oseba uvrščena. 


\section{Tesno povezana in vase zaprta družina}

Štiričlanska jedrna družina, ki jo sestavljajo zakonska partnerja in dva otroka (hči in sin), živi v lastni hiši na vasi. Stiki s starimi starši oz. s staro mamo po mamini strani (stari oče je že pokojen) so vsakodnevni, saj babica živi v sosednji hiši. Stiki s starimi starši po očetovi strani so prav tako vsakodnevni (telefonski pogovori), družinski člani pa jih obiščejo večkrat na teden. Po opisu študentke je v družini čutiti medsebojno zaupanje in spoštovanje, komunikacija med člani, ki si medsebojno nudijo oporo in skrbijo drug za drugega, je dobra. Člani razširjene družine v dejavnostih lokalne skupnosti ne sodelujejo. To nazorno ilustrira izjava mame, ki se ji prireditve $\mathrm{v}$ skupnosti zdijo »brezzveze« in nima nikakršne želje po tem, da bi se družila s sovaščani. To podkrepi z izjavo: »Imamo družinske prijatelje, familijo, in to nam je dovolj.«

Predstavnice treh generacij $\mathrm{v}$ družini smo vprašali, katera je največja dragocenost, vrednota ali nauk, ki so ga prejele od babice, dedka ali druge starejše osebe; njihovi odgovori se precej ujemajo.

MSS-02-Maja-25-1: Od svojih babic in dedka sem prejela veliko naukov. Predvsem je bilo veliko življenjskih modrosti. Mogoče največja dragocenost bi bila ta, da so me prepričali v to, naj v človeku iščem dobro.

MSS-02-Nataša-46-2: Od starejših ljudi sem prejela veliko naukov. Predvsem so bili to dedki in babice ter starši, seveda. To so nauki za življenje, vrednote, kot so: spoštovanje ljudi, medsebojno spoštovanje in podobno.

MSS-02-Ivanka-69-3: Od svojih staršev sem prejela veliko dobrega. Prejela sem veliko znanja, naučili so me spoštovati druge, od staršev sem dobila vrednote. Ne nazadnje so me starši naučili, da spoštujem njih in svoje sestre. Starih staršev nisem poznala.

Na podobno vprašanje, ali so tudi od svojih otrok ali vnukov prejele kakšno vrednoto ali nauk, mama odgovarja, da lahko nauk dobi le od starejše osebe ali vsaj od nekoga enake starosti, od mlajših je kaj takšnega težko dobiti. Babica pa se odgovoru izogne. Iz tega lahko sklepamo, da v družini socializacijo (socialno učenje) razumejo kot enosmeren proces, torej prenos le od starejših k mlajšim članom družine, in ne tudi obratno. Mama, ki ima srednjo strokovno šolo, se ni pripravljena izobraževati v organizirani učni skupini, prizna pa, da se uči od svojih otrok, toda še največ od starejših družinskih članov.

MSS-02-Nataša-46-2: Doma se učim od otrok. Mlajši veliko hitreje dojamejo določene zadeve, recimo kar se računalnika oz. novih računalniških programov tiče, ipd. Od starejših pa se lahko veliko naučiš. Veliko se učiš s tem, ko jih opazuješ, kaj počnejo, poslušaš, kaj ti govorijo, in se učiš na njihovih napakah. Največ pa se naučiš od svojih staršev. Tudi danes se še vedno veliko naučim od svoje mame (oče je že dolgo pokojen). Mama mi še vedno pove, kako je bilo, ko je bila ona mojih let, kaj je takrat storila narobe, tako lahko jaz naredim drugače. Veliko pa se od starejših naučimo življenjske modrosti, ki nam pridejo prav v različnih življenjskih situacijah.

Tudi babica, ki ima poklicno šolo in meni, da je prestara za učenje, se v družinskem krogu uči od mlajših članov.

MSS-02-Ivanka-69-3: Da, od mlajših se učim. Učim se tistih stvar, ki so zame nove. Od mlajših sem se učila, kako uporabljat mobitel, računalnik. Naučili so me vnuki, hčerka in zet, tako da so mi pokazali. 
Mama in babica svoje znanje in izkušnje prenašata na mlajše družinske člane; mama sicer ne navede nobenega primera, babica pa odgovor konkretizira.

MSS-02-Ivanka-69-3: Da, prenašam. Povem jim, kaj sem prebrala, katera so dobra zelišca in kdaj jih vzeti, takšne stvari. Ti mlajši so moji otroci, vnuki.

O tem, ali v družini obstajata vzajemnost in medsebojna pomoč med generacijami (otroki, starši in starimi starši), so intervjuvanke spet dale podobne odgovore.

MSS-02-Maja-25-1: Če gledam družino širše (se pravi, da vključim še dedka in obe babici), potem je odgovor da. Tako mi mlajši pomagamo starejšim članom družine kot tudi oni nam. Za kakšno vrsto pomoči pa gre, je odvisno od posamezne situacije, primera.

MSS-02-Nataša-46-2: Vzajemnost in medsebojna pomoč je $v$ naši družini bila vedno prisotna. Privoščimo si dobre stvari in pomagamo si v slabih stvareh, v težkih trenutkih.

MSS-02-Ivanka-69-3: Vzajemnost in medsebojna pomoč je sigurno prisotna. Vzajemnost in pomoč sta bili prisotni s strani mojih staršev, še posebej mame, ter s strani mojih sester (to je še danes prisotno). Seveda pa je pomoč prisotna tudi med mano in mojo hčerko in njeno družino. Tako da to je bilo vedno prisotno pri nas.

Toda v nadaljevanju pogovora babica $\mathrm{v}$ bistvu ovrže (omaje) svojo izjavo o medsebojni pomoči v družini, ko razmišlja, kako lepo je sama skrbela za svoje ostarele starše, medtem ko ima občutek, da mladi zanjo ne skrbijo dovolj, da tudi njena vloga $v$ družini ni pomembna, saj je vdova in živi sama. Pri tem je opazen njen občutek osamljenosti in izolacije, čeprav živi v sosednji hiši, poleg svojih otrok in vnukov, in so po izjavi študentke stiki z njo dnevni. To njeno doživljanje svojega položaja se močno razlikuje od mnenj nekaterih drugih intervjuvanih predstavnikov tretje generacije, ki so prepričani, da je možnost življenja v bližini mlajših članov družine, toda $\mathrm{v}$ ločenih gospodinjstvih, pogoj za dobre odnose in razumevanje $v$ družini.

\section{Nepovezana družina in različno sodelovanje članov $\mathrm{v}$ skupnosti}

Študentka živi v petčlanski družini z mamo, očimom, polbratom in polsestro. Njen oče je pokojen. Družina prebiva v mestnem blokovskem stanovanju, stari starši (po mamini strani) živijo v predmestju, v hiši, kjer živi tudi ena od njunih hčerk s svojo družino (študentkina teta $\mathrm{z}$ družino). Študentka meni, da v družini ni zaupanja. Sama je čustveno navezana samo na mamo. Komunikacija med družinskimi člani je po njeni oceni bolj »površinska«. Študentka ima mesečne stike s starimi starši, tudi njeni starši imajo s svojimi starši (torej študentkinimi starimi starši) mesečne stike, včasih celo še bolj poredko. Člani ožje družine v skupnosti niso dejavni, medtem ko je babica v svoji lokalni skupnosti zelo dejavna, kar se po mnenju študentke odraža v njeni samopodobi. Babica že nekaj let sodeluje pri dobrodelni organizaciji, pomaga starejšim in bolnim pri domači oskrbi, samostojno je organizirala tudi tečaj usposabljanja za domačo oskrbo.

Pri vprašanju, katera je največja dragocenost, vrednota ali nauk, ki ga je prejela od babice, dedka ali druge starejše osebe, študentka $\mathrm{v}$ ospredje postavlja dedka. Pri tem pa hkrati omenja svoje doživljanje odtujenih odnosov v družini.

MSS-08-Nina-30-1: Menim, da so me naučili predvsem skromnosti. Najljubši spomin pa 
imam na dedka, ki sem mu vsak dan, ko je prišel iz službe, prinesla copate, medtem ko so ostali člani »komaj« opazili, da je prišel domov.

Mama se odgovoru na enako vprašanje izogne in pripoveduje o tem, kako je bila že $\mathrm{v}$ zgodnji mladosti prisiljena $\mathrm{v}$ neodvisno in samostojno življenje.

MSS-08-Irena-49-2: Ma, kaj pa jast vem ... mogoče ga ni pametnejšga od mene (smeh). Ma, recimo, ko sem se mogla že zlo zgodi osamosvojit, se prav, da sm že ful ... kot mlada služla sama dnar, a veš, $k$ sm cajtnge raznašala, pa vse sm si mogla sama kupt, obleke pa to, a ne. V glavnem, hitr sm, zgodi vse delala sama, pa tko naprej ... sm bla bol zgodi samostojna in to se mi še dons pozna. Sej veš, da nism od nobenga odvisna.

Babica postavlja $\mathrm{v}$ ospredje vzgojo in vzorce vedenja svoje mame, ki jih tudi sama posnema in ponavlja.

MSS-08-Olga-70-3: No, jest mislm, da od mame ... kako bi rekla ... naša mama je bla zlo poštena ženska in nas je lepo vzgojila, zlo je bla skrbna, revna, potrpežljiva ... kako bi rekla, nč ni dala iz sebe, da bi jo kej iz tira vrgl. Jst mislm, da isto delam. Sej veš, blo nas je pet ... mama je mela pet otrok, skoz je delala, gostilno čistla, skrbela za nas, vse nas je ona preživljala, $k$ smo bli brez očeta, a ne. Bla je zlo dobra, res dobričina, pa zelo verna. Tko da jst bi rekla, da je name prenesla predvsem to dobroto, pa ... kva bi še rekla ... potrpežljivost, tud za očeta, ki se je ponesreču, nam ni hotla povedat, vse je hotla prekrit. Sam mi otroc ... veš, da smo vedl, da se neki dogaja. Pa pr nam se nikdar ni klel, to pa res. Pr nas je včash rekla prkvt froc ... to je blo.

O tem, ali je od svojih otrok prejela kakšno dragocenost, vrednoto ali nauk, mama odgovarja:
MSS-08-Irena-49-2: Kaj je to ...? Hm, hm ..., da moraš bit ful samozavesten v življenju, da lahko kam prilezeš, moraš včasih kr kakšnga mal pohodit, pa da se ne smeš pustit manipulirat (smeh).

Babica na enako vprašanje ne odgovorja neposredno, ampak poda samorefleksijo o tem, kako lepo je vzgojila svoja otroka:

MSS-08-Olga-70-3: Od svojih otrok bi rekla (ima dve hčerki, op. spraševalke), zdej ne vem, če je to, če to zravn spada. Tist, recimo, $k$ so mi zmeram za rojstni dan pele, to mi res velik pomen. Pa pridne so ble, nobenih problemov nism mela z njima, tko da bi rekla, da je to ena potrditev, da sm jih lepo vzgojila.

Predstavnica tretje generacije ima tudi o svojem položaju v družini zanimivo mnenje, ki odraža visoko stopnjo samozavesti.

MSS-08-Olga-70: Kapo di banda (smeh)! Mam avto, mam svoj dnar... nisem odvisna od drugih, so bol drugi od mene (smeh). Sej veš ... sem zadnjič klele rekla, ja, merkejte me, da se mi ne bo kej nardil, če ne, nas bo finančna kriza udarla. Pol so se pa tko smejal ...

Toda v nadaljevanju pogovora kritično oceni odnose v družini in meni, da mlajši ne spoštujejo starejših.

MSS-08-Olga-70: Razumevanje bi mogu bit ... sam doskat ..., če včasih kej rečem ..., to Jasna koj zavpije ..., to ni nobenga spoštovanja ... glih zdele en dan se je drla na mene. Pa boh ne dej, da bi jih vprašala, kje so bli cel dan.

Vzajemnost in medsebojna pomoč med generacijami v družini sta po mnenju intervjuvank razumljeni kot enosmerna pomoč, ki jo stari 
starši nudijo mlajšim v družini. Vse tri intervjuvanke govorijo izključno o instrumentalni opori, ki pa med generacijami ni vzajemna.

MSS-08-Nina-30-1: Kolikor sem seznanjena, poteka (materialna) pomoč starih staršev predvsem eni hčerki. Ostali otroci in vnuki niso deležni pomoči.

MSS-08-Irena-49-2: ‘̌e otroc pomagajo kej al kaj? Se pravi ... ja, otroci tko, tko, pomagajo bolj slabo. Ata je pomagu, ko je belu, mama pomaga na ta način, kokr lahko, recimo zmerm kakšno zelenjavo prnese, ki jo sama pridela. V tem stilu pomoč.

MSS-08-Olga-70-3: Sej veř, jstsm še zlo samostojna, še zmeram vozm, delam, jst druge oskrbujem, ne drugi mene. Edin mogoče, če kdaj kej nucam iz štacune, mi pa prnesejo. Al pa če grem na pregled za oči, $k$ mi tm dajo ene kaplce, $k$ pol ne smeš vozit. Takrt me že pride kdo iskat, a ne.

Mama, ki ima končano srednješolsko izobrazbo, na vprašanje, ali se rada uči, odgovori, da se ji enostavno ne da, ne ljubi se ji sedeti za knjigami in se učiti. Tudi na vprašanje, ali se uči od mlajših v družini, najprej odgovori nikalno, po premisleku pa ugotovi, da se s posnemanjem svoje hčerke uči odločnosti in samozavesti.

MSS-08-Irena-49-2: Ojoj, hm, ne vem, ne da bi jast vedla, da se kej naučim od mlajših ... Odločnost, samozavest ..., če se to človk nauči, potem ..., to sem se pa res naučila. Sam to sem lahko edin od tebe pobrala, ker če pogledam vse ljudi okol mene, edin ti nastopaš zlo odločno ... Ne vem, pri kakšnih ugovorih al pa ... ne vem, če ti kej ni všeč, takoj vse obrneš na glavo ... in pol $k$ jast to slišm, dobim samozavest in razmišlam, da morm bit tud jst tko samozavestna in odločna kokr ti, a ne. Tko da, tuki gre po mojem za bolj tko, življenjsko učenje, $v$ bistvu te probam posnemat.

Mama je tudi glede možnosti učenja od starejših v družini najprej skeptična, toda po premisleku odgovori, da bi se od svoje mame lahko naučila kaj v zvezi s kuhanjem.

MSS-08-Irena-49-2: Kva pa bi se lohk naučila od njih, kva pa vem ... Ja, mogoče na primer od mame kšno kuhinjo, če mi kej ni jasno, lohk njo kej vprašam, $k$ obvlada vse, kar je v zvezi s kuho... Učim se tko, da mi pokaže, lahk pa samo tud pove, če jo na primer pokličem po telefonu.

Babica, ki ima končano srednjo šolo, se še vedno uči, ker meni, da se mora, ker je tako seznanjena $\mathrm{z}$ novostmi na področju svojega delovanja in $\mathrm{s}$ tem tudi krepi svoje umske sposobnosti. To slikovito opiše v svojem odgovoru.

MSS-08-Olga-70-3: Jah, kva pa vem. Ja, drgač se rada, pa morm se, tm $k$ delam, recimo. Jst morm bit recimo povsod na tekočem, pr teh privatnikih, $k$ jim knjižim, a ne. Kako bi ti rekla ..., da vzdržujem svoje možgane, da sem ... vi ta mlad bi rekl ... da sm fit. Se prav, zaradi glave, da si bistriš um, da ne zastaraš, da ne dobiš tisto ... kako se že reče ... sklerozo. Zarad tega, zarad sebe, a ne.

Babica dopušča tudi možnost, da bi se od mlajših lahko naučila kakšne nove izraze, vendar v nadaljevanju zvemo, da do tega učenja $\mathrm{v}$ bistvu ne pride.

MSS-08-Olga-70-3: Se, velik na izrazih, $k$ jst sm zastarel tip, pa ... ta mlad več vejo, ampak nam rekla pr matematki $k$ jo še dost obvladam (smeh) ... ampak druge stvari. Jst včas poslušam, sploh ne vem, zakva se gre, to mata (njeni dve hčeri, op. spraševalke) take izraze 
... tko da sm raj dostkrat kr tih, nočm pa skoz spraševat, kva to pomen. Glih zdele en dan sta klele prou anglešk klofale. Sej sem rekla, da jih bom enkrat kr vn nagnala. Pa ni blozdej prvič ...

Predstavnica tretje generacije svoje znanje in izkušnje selektivno prenaša na mlajše družinske člane; pripoveduje samo o eni od svojih hčera, drugih mlajših članov družine ne omenja.

MSS-08-Olga-70-3: Ja, to pa prenašam. Mojci (hčerka) pokažem knjiženje, kako se kej dela, a ne. Pa recimo povem ji natančno, kako je treba oskrbovat bolnika, $k$ bo to tud ona enkrat prevzela. Ja, prenašam, ja. Tko, da ji povem, a ne. Za tole knjiženje ji pa kr pokažem, a ne, $k$ mam knjigo doma ... bolnika nimam, a ne (smeh).

Mama svoje znanje in izkušnje prenaša na mlajše s pogovorom in kot primer opisuje, kako sinu govori o odgovornosti.

MSS-08-Irena-49-2: Ja, izkušnje, tko, da se čim več pogovarjaš z njimi ... konkretnga primera pa ... ne vem kva ... no, recimo Markotu ves čas govorim, kako je treba bit odgovoren ... kar pomen, če nardi napako, mora za njo tud prevzet odgovornost in sam rešit težavo. Ne pa, da mu pol mamica skače na pomoč.

Iz navedenega primera družine lahko razberemo, da so stiki med generacijami v razširjeni družini bolj redki, prevladuje odtujenost, primanjkuje toplih in odprtih odnosov. Predstavnica tretje generacije ima tesnejše, toda hkrati ambivalentne odnose le $\mathrm{z}$ družino ene od hčerk, s katero živi v isti hiši. V družini sta opazno okrnjena medgeneracijska pomoč in vzajemno učenje, saj intervjuvanke vzajemnost doživljajo kot enosmeren proces, ki v glavnem poteka od starejših k mlajšim čla- nom družine. Zanimiva je primerjava odnosa do učenja med mamo in babico, ki imata obe srednješolsko izobrazbo. Babica, ki je še vedno zelo dejavna $v$ skupnosti, se $v$ nasprotju s svojo hčerko zaveda vrednosti vseživljenjskega učenja za svoje delovanje in za lastno umsko kondicijo.

\section{POVEZANA IN V SKUPNOST ODPRTA DRUŽINA}

Tričlanska jedrna družina (mama, oče in hči) prebiva $\mathrm{v}$ hiši $\mathrm{v}$ središču manjšega mesta. Oboji stari starši (tako mamini kakor tudi očetovi) živijo v isti soseski. Vsi so tesno povezani, stiki so vsakodnevni, saj živijo skoraj skupaj. Odnosi in komunikacija znotraj družine so zelo dobri. Med seboj si zaupajo in pomagajo tako na finančnem kakor tudi na čustvenem področju. Tudi s sosedi so si zelo blizu. Med seboj se dobro poznajo in si vzajemno pomagajo. Družina je po mnenju študentke zelo odprta za nova spoznavanja in prijateljstva. Vsi družinski člani imajo širok krog prijateljev in znancev. $\mathrm{Z}$ njimi preživijo veliko prostega časa na počitnicah in praznovanjih. Prav tako se ob večjih dogodkih (trgatev, obiranje oljk in podobni dogodki) zberejo vsi sorodniki in prijatelji. Člani družine so dejavni v lokalni skupnosti (sodelujejo pri kulturnih dogodkih, društvih in ohranjanju naravne in kulturne dediščine, babica s prijateljicami organizira plesne večere za starejše, enkrat na leto organizira vaški praznik ob godu zaščitnika vasi in podobno). Navezanost družine na sosesko je po mnenju študentke velika.

Prenašanje vrednot ali naukov s starejših na mlajše člane v družini so predstavnice treh generacij slikovito opisale. Poleg vrednot, kot npr. poštenost in delavnost, se v družini iz roda $\mathrm{v}$ rod prenaša tudi skrb za naravno okolje. 
MSS-21-Anja-22-1: Obe babici in dedek so veliko pripomogli k temu, kar sem. Še posebej zato, ker so oni skrbeli za mene, preden sem začela obiskovati šolo, kajti vrtca nisem obiskovala. Največ in najbolj življenjske nauke mi je dajal dedek. V spominu pa imam tega, $v$ katerem opozarja na nevarnosti, ki nas čakajo, če ne bomo pazili na naše okolje in brzdali naš pohlep. Pravi, da naj se bojimo dneva, ko bodo kokoši nosile jajce popoldne, ko bodo sodniki golobradci, župniki trgovci.

MSS-21-Katja-46-2: Od starejših ljudi sem izvedela resnično veliko. Oni so polni znanja in izkušenj, samo prisluhniti jim je potrebno. Največ mi pomeni to, da so mi starejši ljudje predstavili poštenost kot vrednoto. Poleg tega pa so veliko govorili o ohranjanju narave.

MSS-21-Majda-65-3: Nonoti so pravili, da je delo vrednota, ki daje človeku moč. Spomnim se svojih nonotov kot pomembne, pametne može, ki so bili spoštovani.

Da v družini obstajata vzajemnost in medsebojna pomoč med generacijami, s svojo izjavo potrjuje predstavnica 1 . generacije.

MSS-21-Anja-22-1: Ja. Kot sem že omenila, je naša družina zelo povezana. Ko katerikoli član naše družine potrebuje pomoč, mu ostali priskočimo na pomoč. Tako $v$ dobrih trenutkih kakor tudi $v$ žalosti ali bolezni.

Tudi mama s svojim odgovorom potrjuje, da v družini stari starši pomagajo mlajšim članom družine in obratno.

MSS-21-Katja-46-2: Že od malega sem živela in odraščala $v$ istem gospodinjstvu s starši in starimi starši. Ko so bili starši odsotni, me je babica pazila. Kasneje, ko so ostareli, pa sem sama za njih skrbela. Prav tako se dogaja z mojo družino. Moji starši so pazili na mojo hčerko.
$\mathrm{Z}$ mnenjem hčerke in vnukinje se prav tako strinja babica.

MSS-21-Majda-65-3: Ja. Odkar se spomnim, so bili v hiši pranonoti in pravnuki. Skupaj so se igrali, delali, kuhali, se smejali in počivali. Saj ni važno, koliko je človek star, ampak kako dobro srce ima (smeh).

Mama, ki je končala podiplomski študij in se še naprej izobražuje, se rada uči tudi od mlajših in starejših v družini.

MSS-21-Katja-46-2: Od starejš̌h sem se učila kar veliko. Vse starejše jemljem kot bolj modre, zato se mi zdi smiselno prisluhniti njihovih nasvetom, kasneje pa pri sebi ovrednotim smiselnost povedanega. Tudi od svoje hčerke sem se dosti naučila. Gre predvsem za pogovore, ko izmenjava mnenja in izkušnje.

Babica, ki ima končano osnovno šolo, na šolanje nima lepih spominov, zato se tudi ni pripravljena vključiti $\mathrm{v}$ organizirano učno skupino.

MSS-21-Majda-65-3: Ne. Jaz sem prestara. Berem rada, $v$ šolo pa ne bi šla. Na šolo imam slabe spomine. Najprej to, da sem morala eno uro pešačiti od doma, potem so bili strogi učitelji, tudi tepli so nas. Moji starši niso imeli dosti denarja in sem morala dosti delati doma, nisem imela časa za učit. Potem sem bila kregana.

Kljub slabim izkušnjam iz šole pa se babica z veseljem uči od mlajših članov družine, kar potrjuje tudi njena izjava:

MSS-21-Majda-65-3: Vnuki mi dosti pomagajo. Naučili so me, kako delat z računalnikom in mobitelom. Zdaj, ko imam nov mobitel, se ne spoznam na njega, ampak si mi ti pomagali. Pa moja hčerka rešuje dokumente, 
ki jih ne razumem. Večino stvari naredim sama, ampak danes je ta svet tako napredoval, da ne vem vsega.

Prav tako babica rada pomaga mlajšim družinskim članom s svojim znanjem, ki si ga je pridobila z izkušnjami. Najbolj je zadovoljna, ko vidi, da so njeni nasveti nekomu koristili in je ta dosegel želeni rezultat.

MSS-21-Majda-65-3: Ja, če me vprašajo, rade volje povem. Danes sem ti razložila, kako se naredi brinovo žganje.

Iz odgovorov predstavnic vseh treh generacij je razvidno, da gre za povezano in hkrati v skupnost vpeto družino, ki je zelo naklonjena medgeneracijskemu dialogu. Družinski člani, ki živijo v prostorski bližini, se veliko družijo, vzajemno si izmenjujejo tako instrumentalno kot emocionalno in informacijsko oporo. Vzajemno pomoč in medgeneracijsko učenje dojemajo dobesedno, saj poteka tako od starejših članov k mlajšim članom družine kakor tudi obratno.

\section{SKLEP}

Pomen proučevanja medgeneracijskega sodelovanja in učenja izhaja iz ugotovitev raziskovalcev, ki proučujejo demografske spremembe v družini (Uhlenberg, 1996; Bengtson 2001; Attias-Donfut in Segalen, 2002) in ugotavljajo, da je trajanje družinskih vezi med generacijami danes bistveno daljše kot v preteklosti. Zaradi podaljševanja življenjske dobe živijo tri ali celo štiri generacije sočasno, kar vzpostavlja nove odnose terdaje možnosti za vzajemno pomoč in učenje. To potrjuje tudi vzorec družin v naši raziskavi. Večina 1. generacije pozna svoje stare starše, medtem ko največ intervjuvancev 3 . generacije nima spominov na svoje stare starše, nekateri so jih omenili le v smislu, da jih niso poznali, ker so umrli pred njihovim rojstvom ali takrat, ko so bili sami še majhni. V našem vzorcu pa imamo tudi družino, v kateri živijo štiri generacije in 90-letna prababica poroča o svoji skrbi za pravnuke, ki jim po svojih sposobnostih pomaga pri učenju in šolskih nalogah.

Analiza socialnih interakcij in vzajemnega učenja v zbranih primerih družin potrjuje domneve, da sta socialna interakcija in struktura odnosov med družinskimi člani zelo odvisni od notranjih dejavnikov posamezne družine, ki vplivajo na vloge posameznih članov, na potek komunikacije in pestrost vzajemnega učenja $v$ razširjeni družini, po drugi strani pa tudi od zunanjih dejavnikov, npr. družbenih norm in vrednot ožje in širše skupnosti, kompleksnosti zunanjega okolja, v katerem biva družina, socialno-ekonomskega položaja družine in socialnih omrežij družinskih članov. Iz analize primerov $\mathrm{v}$ raziskavi lahko razberemo zvezo med pogostostjo stikov, komunikacije in intenzivnostjo odnosov treh generacij ter prenašanjem vrednot in vzajemnim učenjem $\mathrm{v}$ družini. $\mathrm{V}$ primeru družine, v kateri prevladujejo odnosi močne povezanosti med predstavniki treh generacij, smo zaznali doživljanje vzajemne pomoči kot nekaj obligatornega. Močno družinsko omrežje in visoka stopnja zaupanja $v$ takšnem omrežju zmanjšujeta tudi potrebo po organiziranem izobraževanju. To je potrdila že raziskava, ki jo je izvedla Strawn (2003: 57); ljudje z močnim in povezanim družinskim omrežjem se vključujejo v priložnostno učenje znotraj tega omrežja in ne iščejo možnosti izobraževanja v skupnosti. Tudi v naši analizi primera tesno povezane in zaprte družine smo prišli do podobnih ugotovitev. Mama in babica nista zainteresirani za sodelovanje v kakšni od učnih skupin, toda obe poročata o vzajemnem učenju, ki poteka med vsemi tremi generacijami v družini. 
Uhlenberg in Mueller (2003) ugotavljata, da se pripravljenost za vzpostavljanje skupnostnih vezi in vzorci dejavnosti v skupnosti prenašajo iz generacije v generacijo, kar velja zlasti, če so starši v času odraščanja svojih potomcev v skupnosti dejavni in čutijo pripadnost skupnosti. Do podobnih ugotovitev smo prišli tudi v naši študiji primerov. Vzorci sodelovanja in vpetosti družinskih članov v socialno okolje se v primerih odnosno povezanih družin prenašajo od starejših k mlajšim generacijam. V tesno povezani in zaprti družini, v kateri nobena generacija ne sodeluje v skupnosti, socialno učenje v družini poteka bolj kot enosmeren proces, od starejših $\mathrm{k}$ mlajšim članom. $\mathrm{V}$ povezani in $\mathrm{V}$ skupnost odprti družini pa obstajata intenzivna in neposredna interakcija ter recipročno, dvosmerno učenje. Izjema je primer odnosno nepovezane družine, $\mathrm{v}$ kateri je predstavnica tretje generacije izjemno dejavna v svoji lokalni skupnosti, medtem ko člani ožje družine v skupnosti ne sodelujejo. V tej družini sta opazno šibka komunikacija in omejeno vzajemno učenje. Iz navedenih primerov lahko tako razberemo povezavo med odnosno bližino, vpetostjo v socialno okolje in vzajemnostjo pomoči, sodelovanja in učenja $v$ družini. Socialno učenje, ki poteka v družini, je torej tesno povezano s siceršnjimi interakcijami, komunikacijo in kakovostjo odnosov v družini. Te ugotovitve potrjujejo tudi redke obstoječe raziskave; npr. Čačinovič Vogrinčič (1992: 76) ugotavlja, da je v nepovezanih družinah komunikacija šibka in neučinkovita, $v$ pretirano povezanih družinah pa tako intenzivna, da lahko onemogoča spremembe.

Analiza vseh intervjujev kaže, da 3. generacija v večini družin na mlajše prenaša vrednote, kot so poštenost, vztrajnost, delavnost, skromnost, pridnost, spoštljivost, resnicoljubnost, varčnost, ohranjanje družinske tradicije itd., ter praktična, uporabna znanja in spretnosti, kot so različne ročne spretnosti, kuhanje, vzgojni nasveti. V naši raziskavi kar nekaj intervjuvancev 2. in 3. generacije meni, da se od mlajših ne učijo in ne prevzemajo njihovih vrednot. Kot ugotavlja Clausen (v Uhlenberg in Mueller, 2003: 126), vključuje socializacija namerno kot tudi nenamerno prenašanje stališč in vedenja med generacijami, zato predpostavljamo, da se tudi v našem primeru, če med člani družine obstaja vsaj določena stopnja interakcije, stališča nezavedno prenašajo ter vplivajo na trenutno in kasnejše življenje vseh članov družine. Drugi intervjuvanci v nasprotju s prejšnjimi navajajo, da jim mlajši dajejo veselje do življenja, optimizem, iskrenost, prijaznost, neustrašnost itd., mnoge starejše pa mlajši učijo tudi uporabljati novo tehnologijo (npr. računalnik, mobilni telefon, digitalni fotoaparat itd). Kot opisujejo intervjuvanci, gre za implicitne učne procese, ki potekajo spontano med vsakodnevnimi opravili in pogovori, z opazovanjem, posnemanjem ali demonstracijo. Na podlagi analize primerov družin lahko ugotovimo, da je učenje v družini v resnici integralni proces - kot ga opredeljuje Illeris (2004: 19) -, ki temelji na interakciji ter vključuje kognitivno, emocionalno in družbeno oz. socialno komponento, te pa se med seboj tesno prepletajo. $\mathrm{V}$ tem procesu spontano prihaja do ponotranjanja naučenega, do osebno pomembnega ali signifikantnega učenja (Rogers, 1994), ki je povezano z življenjskimi problemi. $V$ analiziranih družinah gre za priložnostno učenje, ki ga lahko povežemo z opredelitvami $\mathrm{v}$ teoriji situacijskega učenja $\mathrm{v}$ vsakdanjih dejavnostih (»theories of situated every day practice«) (Lave, 2009: 201); lahko govorimo tudi o učenju posameznikov $\mathrm{v}$ skupini, v tem primeru v družini, ki poteka ob vzajemnih socialnih virih in odnosih v kontekstu skupnosti, kar Wenger (2009: 211) uvršča v socialno teorijo učenja (»social theory of learning «). Na podlagi vzajemnega učenja se spreminjajo razumevanje, čustva in vrednote družinskih članov. 
Opazili smo, da v družinah, kjer je veliko odprte komunikacije, sodelovanja, vzajemne pomoči in učenja, 3. generacija svoj položaj v družini opisuje pozitivno (npr. da so pomembni, spoštovani, povezovalci družine), medtem ko v družinah, kjer prevladujejo šibko vzajemno sodelovanje, pomoč in učenje, starejši svoj položaj predstavljajo z ironičnimi ali trpkimi izjavami, kot npr. »sem samo služkinja, vsem na voljo« ali pa »sem gospodinja in nič več«. Nekateri intervjuvanci opozarjajo tudi na težave $\mathrm{v}$ medgeneracijskem razumevanju in komunikaciji. Med njimi predvsem predstavniki 3. generacije menijo, da jih mlajši v družini ne upoštevajo in ne spoštujejo, pogosto pogrešajo več druženja $\mathrm{z}$ mlajšimi družinskimi člani; mnogi starejši hkrati navajajo, da mlajše razumejo, saj je 2. generacija prezaposlena, podaljšuje se delovni čas in to je glavni razlog, da zmanjkuje časa za družino. Po mnenju 1. in 2. generacije do občasnih konfliktov prihaja zaradi različnih življenjskih nazorov treh generacij; še zlasti stare starše v nekaterih družinah doživljajo kot dominantne in konzervativne, njihova pomoč včasih preraste $\mathrm{v}$ ukazovanje, nadzorovanje in vtikanje v osebne stvari mlajših družinskih članov. Ena od predstavnic 3. generacije pa je prepričana, da se tudi iz konfliktov lahko vsak kaj nauči, pogoj pa je, da se konflikti rešujejo s pogovorom in veliko mero potrpežljivosti. Kot ugotavlja tudi Reiss (v Fitzpatrick in Ritchie, 2004: 577), se skozi reprezentacije interakcij v družini rešujejo različni problemi, ostaja pa vprašanje, kako različne družinske strukture z vzajemnim vplivanjem in učenjem morda tudi neugodno vplivajo na nekatere družinske člane.

Rezultati raziskav kažejo, da v Sloveniji kljub vtisu, da pomen in funkcija družine slabita, prebivalci še vedno visoko vrednotijo družino in njena omrežja socialne opore (Hlebec, 2009). Tudi v naši raziskavi ugotavljamo, da čeprav sta pogostost stikov in intenziteta odnosov vzajemnosti različni, skoraj v vsaki družini poteka neke vrste učenje, ki spodbuja sodelovanje in dajanje pomoči med generacijami ali pa vsaj pripomore $\mathrm{k}$ vzpostavljanju medosebnih odnosov.

\section{LITERATURA}

Albertini, M., Kohli, M., Vogel, C. (2007). »Intergenerational transfers of time and money in European families: common patterns, different regimes? «Journal of European Social Policy, 17 (4): 319-334.

Alwin, D. F., McCammon, R. J. (2003). »Generations, Cohorts and Social Change «. V: Mortimer, J. T., Shanahan, M. J. (ur.), Handbook of the Life Course. New York.

Attias-Donfut, C., Segalen, M. (2002). »The Construction of Grandparenthood «.Current Sociology, 50 (2): 281-294.

Bawin-Legros, B. (2002). »Introduction - Filiation and Identity: Towards a Sociology of Intergenerational Relations«. Current Sociology, 50 (2): 175-183.

Beck, U. (2009): Družba tveganja: na poti v neko drugo moderno. Ljubljana: Krtina.

Bengtson, V. L. (2001). »Beyond the Nuclear Family: The Increasing Importance of Multigenerational Bonds«. Journal of Marriage and Family, 63 (1): 1-16.

Bengtson, V. L., Allen, K. R. (2004). »The Lifecourse Perspective Applied to Families Over Time«. V: Boss, Pauline G. (ur.), Sourcebook of Family Theories and Methods. New York.

Berger, P. L., Luckmann, T. (1988). Družbena konstrukcija realnosti. Ljubljana: Cankarjeva založba.

Čačinovič Vogrinčič, G. (1992). Psihodinamski procesi v družinski skupini. Ljubljana: Advance.

Fitzpatrick, M. A., Ritchie, L. D. (2004). »Communication Theory and the Family«. V: Boss, P. G. (ur.), Sourcebook of Family Theories and Methods. New York. 
Gauthier, A. (2002). »The role of Grandparents«. Current Sociology, 50 (2): 295-307.

Goody, J. (2003). Evropska družina: zgodovinsko-antropološki esej. Ljubljana: Založba /*cf.

Haralambos, M., Holborn, M. (1999). Sociologija. Ljubljana: DZS.

Harris, D. K. (2007). The Sociology of Aging. Plymouth: Rowman\& Littlefield Publishers.

Hlebec, V. (ur.) (2009). Starejši ljudje v družbi sprememb. Maribor: Aristej.

Illeris, K. (2004). The Three Dimensions of Learning. Frederiksberg: Roskilde University Press.

Jarvis, P. (1992). Paradoxes of Learning. San Francisco: Jossey-Bass.

Kemp, C. L. (2007). »Grandparent-Grandchild Ties: Reflections on Continuity and Change Across Three Generations«. Journal of Family Issues, 28 (7): 855-881.

Laszloffy, T. A. (2002). »Rethinking Family Development Theory: Teaching with the Systemic Family Development Model«. Family Relations, 51: 206-214.

Lave, J. (2009). »The practice of learning«. V: Illeris, K. (ur.), Contemporary Theories of Learning. London.

Martin-Matthews, A. (2006). The Ties that Bind Aging Families. TheVanier Institute of the Family. Dostopno prek: http://www.vifamily.ca/library/cft/ aging.html (4. 8. 2009).

Mead, G. H. (1997). Um, Sebstvo, Družba. Ljubljana: Krtina.

Popenoe, D. (1993). »American Family Decline, 1960-1990: A Review and Appraisal «. Journal of Marriage and the Family, 55 (3): 527-542.

Putney, N. M., Bengtson, V. L. (2003). »Intergenerational Relations in Changing Times «. V: Mortimer, J. T., Shanahan, M. J. (ur.), Handbook of the Life Course. New York etc.

Rogers, C. (1994). Freedom to Learn. New York, Toronto: Maxwell Macmillan International.

Silverstein, M., Bengtson, V. L. (1997).»Intergenerational Solidarity and the Structure of Adult ChildParent Relationships in American Families«. American Journal of Sociology, 103 (2): 429-460.
Silverstein, M., in drugi. (2002).»Reciprocity in parent-child relations over the adult life course The Journal of Gerontology, 57B, 1: S3-S13.

Strauss, A. L., Corbin, J. (1990). Basics of Qualitative Research: Grounded Theory Procedures and Techniques. Newbury Park: Sage.

Strawn, C. L. (2003). The Influences of Social Capital on Lifelong Learning among Adults who did not Finish High School. Cambridge: NCSALL.

Uhlenberg, P. (1996). »Mutual attraction: Demography and life-course analysis«. The Gerontologist,36 (2): 226-229.

Uhlenberg, P., Mueller, M. (2003).»Family Context and Individual Well-Being«. V: Mortimer, J. T., Shanahan, M. J. (ur.). Handbook of the Life Course. New York etc.

Ule, M. (2000). Sodobne identitete v vrtincu diskurzov. Ljubljana: Sofia.

Ule, M., Kuhar, M. (2003). Mladi, družina, starševstvo. Ljubljana: Fakulteta za družbene vede.

Vollenwyder, N., in drugi. (2002). »The Elderly and their Families, 1979-1994: Changing Networks and Relationships«. Current Sociology, 50 (2): 263-280.

Wenger, E. (2009). »A social theory of learning «. V: Illeris, K. (ur.), Contemporary Theories of Learning. London, New York.

1. Razširjeno družino Murdock opredeljuje kot družino, ki je večja od jedrne in se lahko razširi vertikalno (z dodajanjem članov drugih generacij) ali horizontalno (z dodajanjem članov generacije, ki ji pripadata starša, npr. tet, stricev, drugih parov) (v Haralambos, Holborn, 1999: 325-326). Razširjeno družino lahko opredelimo tudi kot družino, ki jo sestavlja več povezanih jedrnih družin, kjer je odnos starš-otrok razširjen tako, da gre za tri- ali večgeneracijsko družino (par, njuni otroci s partnerji ali brez, vnuki) (Harris, 2007: 155).

2. Jedrno družino sestavljata vsaj dve generaciji; v zgodnjih opredelitvah je jedrna družina razumljena kot najmanjša družinska enota, ki »jo tvorijo mož, žena ter njuno nedoraslo potomstvo« (Haralambos, Holborn, 1999: 325; Harris, 2007: 155), v novejših pa kot družina, ki jo sestavlja vsaj eden od staršev in otrok. 
3. Murdock (v Haralambos, Holborn, 1999: 329) opredeljuje štiri temeljne funkcije, ki so značilne za vsako družino: seksualno, reproduktivno, ekonomsko in vzgojno (socializacija), Parsons pa kot funkciji družine omenja »primarno socializacijo otrok« (ponotranjenje družbene kulture in strukturiranje osebnosti) ter »stabilizacijo odraslih oseb v družbeni populaciji« (gre za čustveno varnost, ki jo zagotavlja jedrna družina zlasti v času, ko razširjena družina ne daje več prave opore) (Parsons v Haralambos, Holborn, 1999: 330).

4. Ukvarjal se je s skupnostno in družinsko sociologijo ter zlasti proučeval družinske odnose v različnih družinskih strukturah in različnih okoliščinah.

5. Stari starši so vse bolj zdravi in čili, mnogi imajo več denarja in več časa kot v preteklosti. Po drugi strani pa so starši vse bolj vpeti v izobraževanje in delo in imajo manj časa za svoje otroke. Zlasti matere so pogosteje zaposlene in uspešne v karieri, tako da bolj potrebujejo pomoč starih staršev, katerih vloga je pri socializaciji vnukov izrednega pomena.

6. Uhlenberg (1996) je proučeval dostopnost pomoči med sorodniki v ZDA in ugotovil, da je za današnje 20-letnike bolj verjetno, da bodo imeli živo staro mamo, kot je bilo za rojene leta 1900 verjetno, da bodo imeli živo mamo. Ugotovil je tudi, da so imeli otroci, rojeni leta 1900, kar 18 odstotkov možnosti, da postanejo sirote (da jim starši umrejo pred 18 . letom starosti), medtem ko imajo otroci, rojeni leta 2000, 68 odstotkov možnosti, da bodo imeli pri 18 letih žive še vse štiri stare starše. Za primerjavo - le 21 odstotkov rojenih leta 1900 je imelo pri 30 letih živega katerega od starih staršev (Bengtson, 2001: 6).

7. Proučeval je jedrno dvogeneracijsko belo družino srednjega razreda v ZDA v daljšem časovnem obdobju.

8. Poleg modificirane razširjene družine, ki pomeni »zvezo jedrnih družin v stanju delne odvisnosti«, v kateri si člani medsebojno pomagajo, hkrati pa ohranjajo veliko avtonomijo (ekonomsko in geografsko razdaljo), kar to družino razlikuje od klasične razširjene družine (Litwak, v Haralambos, Holborn, 1999: 354), se pojavljajo že omenjene binuklearne družine, »vertikalne« ali »okleščene« družine (»beanpole family« - gre za družino, kjer hkrati živi štiri ali pet generacij z malo potomci, pomembni pa so zlasti vertikalni odnosi), mešane družine (člani družine, ki niso v krvnem sorodstvu, a živijo skupaj), gejevske in lezbične družine (Harris, 2007: 156), reorganizirane družine, pojavljajo pa se tudi oblike socialnega starševstva (Ule in Kuhar, 2003: 49).

9. Beck (2009: 169) pa posledice teh sprememb opisuje tudi kot naraščajočo revščino enostarševskih družin (mater samohranilk), ki so prisiljene - poleg zaposlovanja - prositi tudi za socialno pomoč države, kar kaže na krhkost zakonske in družinske oskrbe.

10.Temeljni raziskovalni projekt, katerega odgovorna nosilka je bila dr. Valentina Hlebec, je potekal od leta 2009 do 2012 (J5 - 2166), v celoti ga je financiral ARRS.

11.Zaradi poenostavitve bomo v nadaljevanju uporabljali le moški spol.

12.Vprašanja za posamezne generacije so se delno razlikovala, vendar le toliko, da so proučevana področja še vedno ustrezno vsebinsko primerljiva.

13.V naši raziskavi se pojem »generacije « prvenstveno nanaša na sorodnike oz. biološke naslednike različnih starosti znotraj iste družine. 